\title{
Introduction to the Ilímaussaq intrusion with a summary of the reported investigations
}

\author{
John C. Bailey, Lotte Melchior Larsen and Henning Sørensen
}

\section{Geology and petrology}

\section{Geological setting}

The Ilímaussaq intrusion belongs to the late Precambrian Gardar province of South Greenland (fig. 1). The province can be regarded as a cratogenic rift province with similarities to the East African rift system and the Oslo igneous province (Upton, 1974; Emeleus \& Upton, 1976). The province consists of continental sandstones, and a variety of volcanic and plutonic igneous rocks many of which are alkaline. An important series of faults have influenced the position of the plutonic centres and presumably facilitated the rise of magma into the upper crust. The alkaline rocks evolved towards Si-rich melts such as comendites and alkali granites, and towards Si-poor melts such as phonolites and nepheline syenites. Both types of evolution are present at Ilímaussaq (fig. 2).

The Ilímaussaq intrusion $(17 \times 8 \mathrm{~km})$ is situated in the mid-eastern part of the Gardar province and has been dated by the $\mathrm{Rb}-\mathrm{Sr}$ isotope method to $1168 \pm 21 \mathrm{~m}$.y. (Blaxland et al., 1976). The position of the intrusion, and its steep margins, suggest that the intrusion was largely emplaced by block subsidence (Sørensen, 1978; Nielsen \& Steenfelt, 1979) into a Precambrian granite basement and the overlying Gardar sandstones and lavas. In the roof zone there are local signs of piecemeal stoping and the final nepheline syenites (lujavrites) intruded nearby country rocks in a few places.

\section{Interim petrologic synthesis}

Important contributions to the petrology of the Ilímaussaq intrusion have been presented by Ussing (1912), Sørensen (1962, 1969, 1970), Ferguson (1970a), Sood \& Edgar (1970), Engell (1972), Bohse et al. (1974), Steenfelt \& Bohse (1975), Larsen (1976, 1977), Sørensen \& Larsen (1978), Karup-Møller (1978) and Konnerup-Madsen et al. (1979). Many other papers contain essential information for a petrological model. We have combined the existing work with the papers presented in this report, and assimilated the current understanding of our Ilímaussaq colleagues, in order to present an interim petrological synthesis.

Geological and geochemical evidence suggests that the intrusion was emplaced in three main pulses - augite syenite, acid rocks, and agpaitic rocks.

Augite syenite stage. An early shell of augite syenite occurs along the sides and roof of the intrusion. It shows an outer chilled margin and local, steeply dipping banding in the wall sections. The magma crystallized successively inwards from the walls. The augite syenite has been regarded by many authors as representative of the parent magma for the Ilimaussaq intrusion, but recent work suggests it is largely cumulitic. 


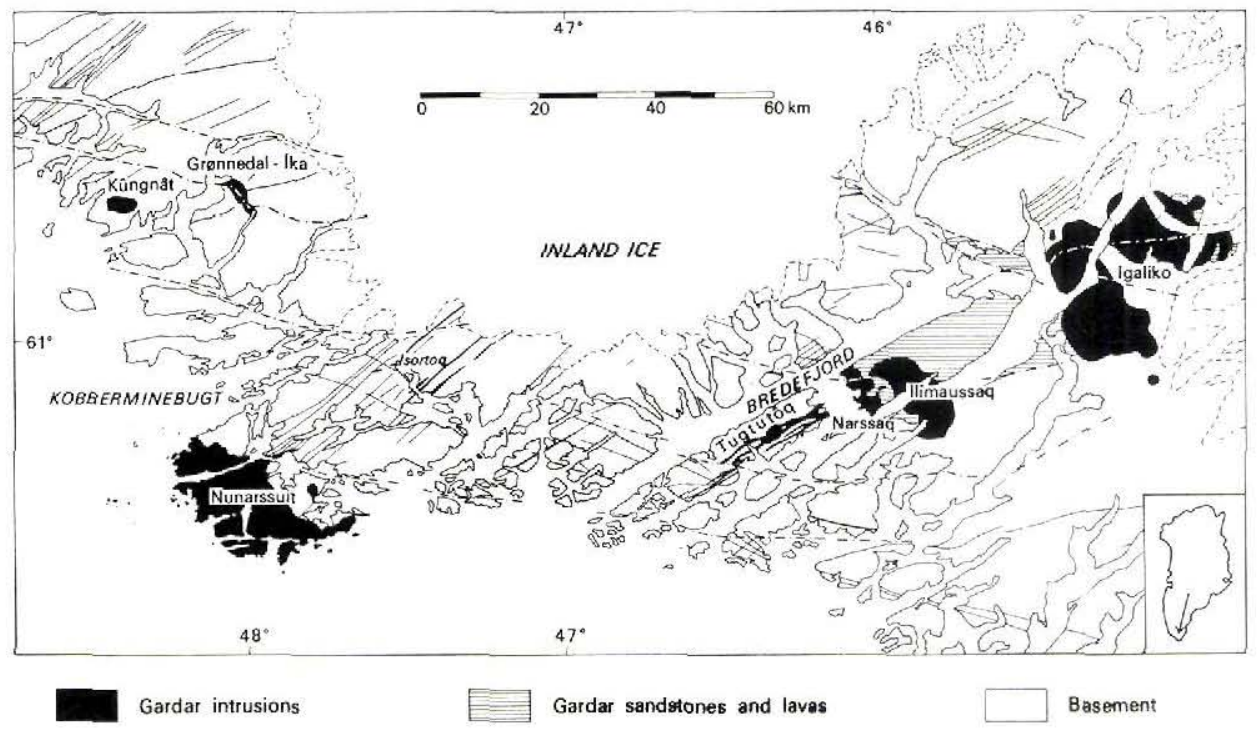

Fig. 1. Simplified geological map of the Gardar igneous province showing the position of the intrusions.

The magma was slightly silica undersaturated and aluminous, with a composition similar to other augite syenites of the Gardar province. Separation of ternary feldspar, olivine $\left(\mathrm{Fo}_{17}-\mathrm{Fo}_{4}\right)$, ferrosalite, $\mathrm{Fe}$-Ti oxide and apatite yielded more alkaline and undersaturated syenites, probably with lower Fe contents. Separation of aluminous phases such as feldspar and ferrosalite would drive residual liquids to a peralkaline state. Pyrrhotite and chalcopyrite probably crystallized from immiscible sulphide droplets in the augite syenite magma.

Alkali acid rock stage. The second pulse of magma was a peralkaline granite magma with geochemical affinities to the other Ilímaussaq rocks. It was emplaced as two sheets in the uppermost part of the augite syenite. The evolution, and the genetic relation of these alkali acid rocks (granite, quartz syenite) to other límaussaq rocks is not clear.

Agpaitic stage. The third, and main, pulse of magma was peralkaline and silicaundersaturated. It formed a layered series of agpaitic nepheline syenites in the centre of the intrusion (see Table 1). This pulse underwent a complex differentiation history. From the magma, the roof rocks pulaskite, foyaite, sodalite foyaite and naujaite crystallized successively downwards; contemporaneous bottom cumulates are inferred to be present at depth. The exposed bottom cumulates, the kakortokites, are younger than the roof cumulates and may have formed from a new pulse of agpaitic magma. The kakortokites pass conformably upwards into lujavrites; the transition probably reflects physical changes in the magma chamber which at this stage measured about $10000 \times 5000 \times 200 \mathrm{~m}$, i.e. disc-shaped. Subsidence and fracturing of the roof, with the establishment of two or more, largely isolated sub-chambers of lujavrite would fit the field and geochemical evidence. At a very late stage, arfvedsonite lujavrite and medium- to coarse-grained (M-C) lujavrite, including those at Kvanefjeld, were intruded. After this event only hydrothermal activity remained.

At the pulaskite-foyaite substage, the cumulate crystallization was dominated by alkali feldspar with lesser amounts of fayalite, hedenbergite, titanomagnetite and apatite. These 


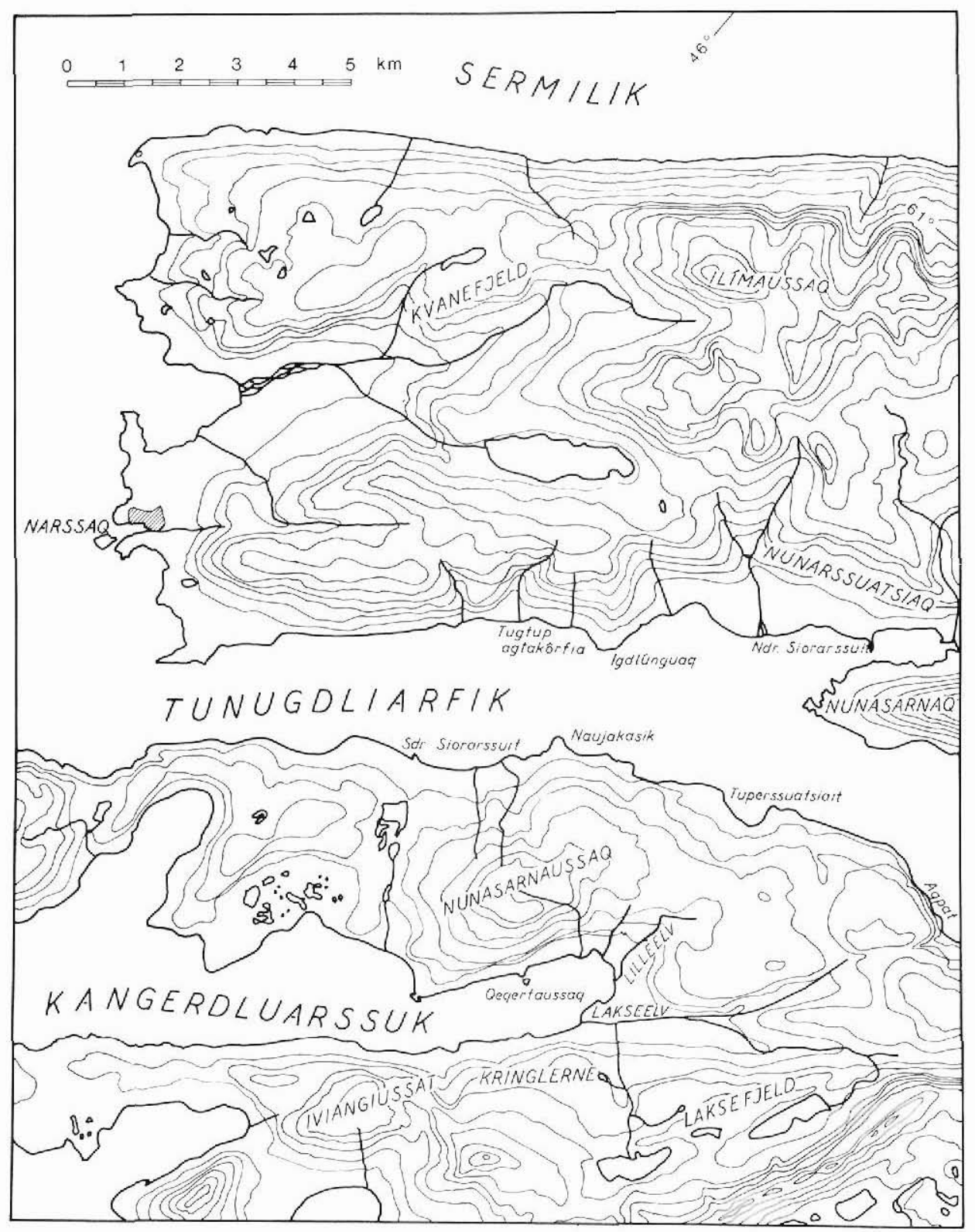

Fig. 2. Topography and names in the region of the Ilímaussaq intrusion.

phases were plastered onto the roof. The magma approached the agpaitic stage, and nepheline, sodalite, alkali amphibole, alkali pyroxene and aenigmatite occur interstitially.

At the transition to the sodalite foyaite-naujaite substage, sodalite and nepheline became additional cumulus phases, and this substage is characterized by the increasingly pronounced 


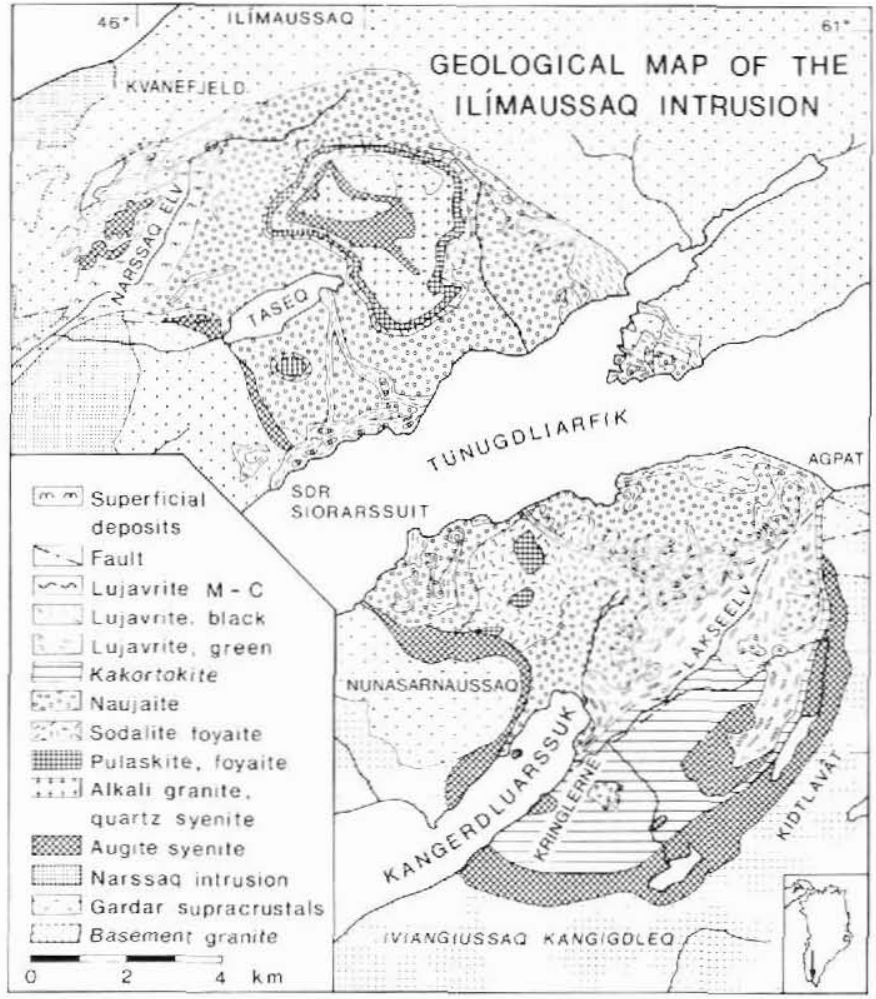

Fig. 3. Geological map of the Ilimaussaq alkaline intrusion. Lujavrite, green includes aegirine lujavrite $\mathrm{I}$ and II and later aegirine lujavrites. Lujavrite, black comprises all the varieties of arfvedsonite-bearing lujavrite including the naujakasite-bearing variety.

flotation of sodalite crystals under the roof. The mafic minerals are dominantly interstitially formed: alkali amphibole, aegirine, aenigmatite and eudialyte. The mafic cumulus phases are the same as in the pulaskite and foyaite, but they are only present in extremely small quantities and an unknown amount of these have dropped out of the crystallising magma. The water-free character of the liquidus mineral assemblage shows that the main magma was water-undersaturated; this stands in marked contrast to the interstitial assemblage. Very low oxygen fugacity which further decreased during crystallization can be deduced from the mineral assemblage (fayalite, aenigmatite, arfvedsonite), the mineral chemistry, and from the presence of hydrocarbon-rich fluid inclusions. Low sulphur fugacity is indicated by the sulphide assemblage troilite-djerfisherite. Uranium contents of the interstitial eudialyte decrease with evolution; this may reflect the increased solubility of $U$ as complex ions in the coexisting volatile $\left(\mathrm{H}_{2} \mathrm{O}, \mathrm{F}\right)$, alkali-rich magma. The magma composition at this stage was fully agpaitic; copious extraction of feldspar, nepheline and sodalite probably reversed the Fe-depletion trend of earlier stages and the later agpaitic rocks are distinctly rich in Fe.

At the kakortokite substage, density-stratified bottom cumulates were developed. They consist of cyclically layered series with units composed of black (arfvedsonite), red (eudialyte) and white (feldspar) layers, named from bottom to top in a unit. Cumulus eudialyte indicates saturation of the magma in $\mathrm{Zr}$, and from this point $\mathrm{Zr}$ contents begin to decline. 
Table 1. The major rock types of the Ilimaussaq intrusion

\begin{tabular}{|c|c|c|c|}
\hline Rock types & Texture, grain size & Essential minerals & Minor minerals \\
\hline augite syenite & $\begin{array}{l}\text { hypidiomorphic to } \\
\text { xenomorphic granular, } \\
\text { massive or banded, medium } \\
\text { to coarse }\end{array}$ & $\begin{array}{l}\text { alkali feldspar, fayalitic } \\
\text { olivine, ferrosalite }\end{array}$ & $\begin{array}{l}\text { titanomagnetite, apatite, } \\
\text { Ti-rich hastingsite, biotite }\end{array}$ \\
\hline $\begin{array}{l}\text { pulaskite and } \\
\text { foyaite }\end{array}$ & $\begin{array}{l}\text { massive, medium to coarse, } \\
\text { platy feldspars }\end{array}$ & $\begin{array}{l}\text { alkali feldspar, hedenbergite, } \\
\text { katophorite, nepheline, } \\
\text { fayalite, alkali pyroxene }\end{array}$ & $\begin{array}{l}\text { apatite, titanomagnetite, } \\
\text { aenigmatite, biotite, } \\
\text { fluorite, eudialyte }\end{array}$ \\
\hline sodalite foyaite & massive, coarse & $\begin{array}{l}\text { alkali feldspar, nepheline, } \\
\text { sodalite, alkali pyroxene } \\
\text { alkali amphibole }\end{array}$ & $\begin{array}{l}\text { fayalite, apatite, magnetite, } \\
\text { eudialyte, aenigmatite, rinkite, } \\
\text { fluorite }\end{array}$ \\
\hline naujaite & poikilitic, coarse & $\begin{array}{l}\text { sodalite, alkali feldspar, alkali } \\
\text { pyroxene, alkali amphibole }\end{array}$ & $\begin{array}{l}\text { eudialyte, rinkite, zeolites, } \\
\text { aenigmatite, nepheline }\end{array}$ \\
\hline kakortokite & $\begin{array}{l}\text { laminated, layered, } \\
\text { medium }\end{array}$ & $\begin{array}{l}\text { alkali feldspar, nepheline, } \\
\text { alkali amphibole, eudialyte }\end{array}$ & $\begin{array}{l}\text { aegirine, aenigmatite, rinkite, } \\
\text { zeolites }\end{array}$ \\
\hline lujavrite & $\begin{array}{l}\text { laminated, fine; and } \\
\text { massive, layered, medium } \\
\text { to coarse }\end{array}$ & $\begin{array}{l}\text { microcline, albite, nepheline, } \\
\text { arfvedsonite, aegirine, } \\
\text { eudialyte }\end{array}$ & $\begin{array}{l}\text { sphalerite, steenstrupine, } \\
\text { monazite, sodalite, zeolites, } \\
\text { Li-mica }\end{array}$ \\
\hline alkali acid rocks & $\begin{array}{l}\text { hypidiomorphic granular, } \\
\text { medium to coarse }\end{array}$ & $\begin{array}{l}\text { alkali feldspar, quartz, alkali } \\
\text { amphibole, aegirine }\end{array}$ & $\begin{array}{l}\text { aenigmatite, eucolite, neptunite, } \\
\text { ilmenite, pyrochlore }\end{array}$ \\
\hline
\end{tabular}

White kakortokite has apparently trapped a significant amount of coexisting magma; it shows adcumulus growth and eventually crystallises accessory rinkite, Li-mica, galena and sphalerite interstitially. Oxygen and sulphur fugacities were still low in the agpaitic magma and accessory troilite, djerfisherite, loellingite, westerveldite and native $\mathrm{Pb}$ occur.

At the lujavrite substage, the earliest rocks (aegirine lujavrite I) reveal a weak development of cumulus horizons and probably occurred as crystal-liquid mushes prior to the weak density stratification. Cumulus K-feldspar, nepheline, aegirine and eudialyte are poikilitically enclosed by arfvedsonite and zeolites which crystallised from an interstitial, residual magma. The overlying lujavrite varieties probably evolve through partial cumulates to virtually liquid compositions. Contents of cumulus eudialyte (and contents of $\mathrm{Zr}$ ) show an overall decrease through the kakortokite-lujavrite sequence. The U content in the eudialyte increases. Interstitial steenstrupine comes to hold more and more of the $U, T h, R E E$ and $P$ in the later lujavrites. Changes from aegirine (green) to arfvedsonite (black) lujavrites are thought to reflect variability in the activity of oxygen and/or water.

The final lujavrite substages are marked by local emplacement of arfvedsonite lujavrite and M-C lujavrite with (?)largely liquid compositions. There are important areas of lujavrite rich in villiaumite and naujakasite. Contents of many rare elements $(F, R E E, P, T h, U, S n$, $\mathrm{Li}, \mathrm{Be}, \mathrm{Ga}$ ) reached their highest values, and the Kvanefjeld uranium deposit was formed. Th and $U$ were partly lost to a fenitic exocontact zone and to hydrothermal veins in the country rocks. Pegmatites and hydrothermal veins, mainly composed of microcline, nepheline, arfvedsonite, aegirine and zeolites, locally contain rare mineral species $(\mathrm{Nb}, \mathrm{Ta}, \mathrm{Be}, \mathrm{Sn}$ minerals, sulphides and antimonides of $\mathrm{Tl}$ and $\mathrm{Cu}$ ). 
Further work is needed to assess the genetic interrelations of the three main intrusive events observed at Ilímaussaq - augite syenite, acid rocks and agpaitic rocks.

It is worth recalling that the Ilimaussaq intrusion is the home of the term "agpaitic" (from the locality Agpat near the eastern margin of the intrusion). The term was introduced by Ussing (1912) as a common denominator for the peculiar nepheline syenites of the intrusion. The term is now used to describe peralkaline nepheline syenites which contain complex volatile-bearing minerals such as eudialyte and rinkite (Sørensen, 1960, 1974). Agpaitic rocks have also been described from the Kola Peninsula (USSR), South Africa, Brazil, and a few other places, but are rare. A growing body of research indicates that the physicalchemical evolution of the Ilímaussaq agpaitic system was distinctly abnormal; its petrological value arises from the contrasting light it throws on the behaviour and properties of normal terrestrial magmas.

\section{Mineralogy}

The mineralogy of the Ilímaussaq intrusion, as discussed in numerous papers and especially by Semenov (1969), reflects its agpaitic nature. The main characteristics are:

(a) silica-undersaturated, peralkaline mineralogy; rock-forming minerals include alkali feldspar (partly as separate microcline and albite), nepheline, sodalite, arfvedsonite, aegirine and eudialyte.

(b) numerous rare minerals of $\mathrm{Li}, \mathrm{Be}, \mathrm{REE}, \mathrm{Zr}, \mathrm{Nb}$, $\mathrm{Th}$, $\mathrm{U}$ etc. reflecting the high contents of these elements.

(c) minerals rich in volatile components $\left(\mathrm{H}_{2} \mathrm{O}, \mathrm{F}, \mathrm{Cl}, \mathrm{S}\right)$ are common, e.g. villiaumite, eudialyte, arfvedsonite, sodalite and sphalerite and numerous other sulphides.

(d) abundance of sodic rather than potassic minerals.

(e) presence of minerals reflecting exceptionally low oxygen and sulphur fugacities, e.g. aenigmatite, arfvedsonite, native elements, westerveldite, troilite and djerfisherite.

Of the nearly 190 minerals, there are about 6 native elements, 26 sulphides, 4 sulphates, 100 silicates, 12 carbonates, 10 arsenides and antimonides, 2 halides, 24 oxides and 6 phosphates.

Various aspects of the mineralogy of Ilímaussaq are still being investigated. The aim is to compile a monographic presentation of the mineralogy of the intrusion.

In the following paper there is a compilation of the almost $\mathbf{1 9 0}$ different minerals which have been identified so far in the Ilímaussaq intrusion and its contact zones. The list is an updated version of earlier lists prepared by Sørensen (1967) and Semenov (1969). The paper also presents a list of the series of papers "Contribution to the Mineralogy of Ilimaussaq" which at the time of completing this manuscript numbered 62 papers.

The discovery of an additional beryllium mineral, helvine $\mathrm{Mn}_{4} \mathrm{Be}_{3} \mathrm{Si}_{3} \mathrm{O}_{12} \mathrm{~S}$, is reported in Johnsen \& Bohse. It occurs in pegmatite pockets in the kakortokites of the Kangerdluarssuk region. Chemical and optical data, density and unit cell dimensions agree closely with those of other examples of essentially pure helvine quoted in the literature.

L.M. Larsen presents new microprobe data on the feldspars and mafic minerals of the augite syenite. The feldspar of the chill zone of the augite syenite is strongly zoned from oligoclase relict cores to sodic K-feldspar. In the innermost facies of augite syenite, the feldspar is sodic K-feldspar with a restricted compositional range. 
The feldspar crystallization path is discussed; it recalls those observed in other intrusions of larvikite-type syenites.

Microprobe analyses of nepheline, magnetite, amphibole and biotite are also presented. There are distinct differences in chemistry between magmatic and subsolidus formed amphibole and biotite.

\section{General geology}

Ussing's interpretation of the geology of the Ilímaussaq intrusion and the sketch map in his 1912 memoir served as the basic reference until a new map was prepared by Ferguson in 1964. Since 1964 smaller regions of combined geological and economic interest have been mapped in considerable detail. This applies to the Kvanefjeld area (Sørensen et al., 1969, 1974), the kakortokites (Bohse et al., 1971) and the Taseq slope (Engell et al., 1971).

A remapping of the part of the intrusion lying to the south of Tunugdliarfik fjord was initiated in 1969 by A. Steenfelt (the foyaite area), A. Demina (the head of Kangerdluarssuk), H. Bohse (the area south of Kangerdluarssuk and Lakseelv) and S. Andersen (the area centered on the Agpat plateau). Results of this mapping are presented in this report in three papers which together constitute the section on General Geology.

The first of these papers presents an outline of the stratigraphy of the southern part of the intrusion which has been established as one of the results of the detailed mapping. The second paper brings together new information about the upper rocks of the intrusion and the third paper gives a more detailed description of the kakortokite-lujavrite sequence.

In the paper by $\mathrm{A}$. Steenfelt strong evidence is presented for the xenolithic nature of the small occurrences of alkali granite and quartz syenite in the pulaskite of the southern part of the intrusion. Thus, bodies of alkali quartz syenite are invariably underlain by inch-scale layered pulaskite and overlain by quartz-contaminated foyaite. Elsewhere, the quartz syenite forms a layer overlying pulaskite and, in the best developed section, is overlain by alkali granite. Both the acid rock types are intrusive into the upper sheet of augite syenite.

The recognition that the alkali acid rocks constitute the second of three main intrusive events at Ilimaussaq greatly clarifies the emplacement history of the intrusion.

The paper by $\mathrm{H}$. Bohse \& S. Andersen demonstrates beyond any doubt that the bottom kakortokites grade upwards into a series of lujavrites. The general profiles are shown in figs 1 and 2 in this paper. The kakortokite series is now divided into three parts: $200 \mathrm{~m}$ lower layered kakortokite (the 'classical' kakortokites), $35 \mathrm{~m}$ slightly layered kakortokite, and 40 $\mathrm{m}$ transitional layered kakortokite. This is conformably followed by the lujavrite series: $80 \mathrm{~m}$ aegirine lujavrite I, $85 \mathrm{~m}$ aegirine lujavrite II, $60 \mathrm{~m}$ lujavrite transition zone and about $150 \mathrm{~m}$ arfvedsonite lujavrite. This bottom sequence is considered to have been built up on a floor which may have formed as a result of major cauldron subsidence.

Igneous lamination steepens towards the external contact and gives an overall saucer shape to the kakortokite-lujavrite sequence. This sequence is separated from the augite syenite by a shell of 'marginal pegmatite'.

In the Agpat region, the arfvedsonite and aegirine lujavrites are cut by schlieren and veins of medium- to coarse-grained (M-C) lujavrite corresponding to the relations at Kvanefjeld (Sørensen et al., 1969).

The geochemistry of the kakortokite-lujavrite sequence is considered in subsequent papers. 


\section{Geochemistry}

The presence of exceptionally high contents of incompatible trace elements $(\mathrm{Cl}, \mathrm{F}, \mathrm{Zr}$, $\mathrm{Nb}$ ) was established by Ussing (1912) and extended to U and Th (Bondam \& Sørensen, 1959), Rb, Li and Be (Hamilton, 1964), S, Cs, Tl, Hf, Ta, REE, Sn, Pb (Gerasimovsky, 1969) and to $\mathrm{Br}$ and $\mathrm{Sb}$ (Bailey et al., 1978). At the same time, contents of $\mathrm{Ca}, \mathrm{Mg}, \mathrm{Ti}, \mathrm{Co}$ and $\mathrm{Sc}$ are distinctly low. Most authors considered these features as evidence for a high degree of fractionation of the Ilímaussaq magma.

Sørensen $(1958,1960)$ recognised that these elements, which frequently escape in pegmatite and hydrothermal bodies, had taken part in the crystallization of the magmas, and their high contents could be used to partly define the agpaitic condition.

Gerasimovsky (1969) drew valuable comparisons with similar agpaitic rocks from Lovozero. Many trace elements show a close association with $\mathrm{Na}$, e.g. $\mathrm{Cl}$ and $\mathrm{S}$ (sodalite), $\mathrm{F}$ (villiaumite), $\mathrm{Zr}$ (eudialyte), $\mathrm{Nb}$ (epistolite), $\mathrm{REE}$ (rinkite, steenstrupine) and Be (chkalovite).

Ferguson (1970b) showed that ratios such as $\mathrm{K} / \mathrm{Ca}$ and $\mathrm{Ti} / \mathrm{Zr}$ gave trends in agreement with (a) the sequence of intrusion based on field evidence and (b) the upwards accumulation of the kakortokites.

Special studies were made on Nb-Ta (Hansen, 1968), Be (Engell et al., 1971), Zr-Nb (Bohse et al., 1971), REE (Gerasimovsky \& Balashov, 1968) and Th-U (many authors).

Fission-track analyses of $U$ in eudialyte provided evidence which could not be explained by fractional crystallization; instead the role of volatiles and complex ion formation was emphasised (Bohse et al., 1974; Steenfelt \& Bohse, 1975; Sørensen \& Larsen, 1978).

Engell (1972) argued that the five-fold concentration of the incompatible elements $\mathrm{Zr}$ and $\mathrm{Be}$ between augite syenite and sodalite foyaite pointed to at least 80 per cent (and probably 90-95 per cent) fractionation before the agpaitic stage was reached. Hence there must be a very large underlying magma chamber.

A $\mathrm{Rb}-\mathrm{Sr}$ isotopic study revealed mantle-type initial ${ }^{87} \mathrm{Sr} /{ }^{86} \mathrm{Sr}$ ratios for the augite syenite but more radiogenic ratios (probably reflecting crustal contamination) for the later agpaitic rocks (Blaxland et al., 1976).

In the present report, the establishment of a detailed stratigraphy for the kakortokitelujavrite sequence has provided the basis for systematic geochemical investigations of these rocks.

In the first paper in the section on Geochemistry it is calculated that the transitional layered kakortokite and the overlying aegirine lujavrite I together contain approximately 25 million metric tons $\mathrm{ZrO}_{2}, 9$ million tons $\mathrm{RE}_{2} \mathrm{O}_{3}$ and 2 million tons $\mathrm{Nb}_{2} \mathrm{O}_{5}$. Combining these tonnages with those in the lower layered kakortokites, the estimated resources at the head of Kangerdluarssuk fjord are thus enlarged to 86 million tons $\mathrm{ZrO}_{2}, 23.2$ million tons $\mathrm{RE}_{2} \mathrm{O}_{3}$ and 8.5 million tons $\mathrm{Nb}_{2} \mathrm{O}_{5}$.

Field and laboratory investigations have been combined in a paper by S. Andersen, J. C. Bailey \& $\mathrm{H}$. Bohse which shows that variations in $\mathrm{Zr} / \mathrm{U}$ and $\mathrm{Zr} / \mathrm{Y}$ ratios can be used to establish a geochemical stratigraphy for the kakortokite-lujavrite sequence in southern Ilímaussaq and to characterise each rock unit. Both these ratios are constant or slightly decreasing through the kakortokite sequence but rapidly decrease through the lujavrite sequence, i.e. with progressive crystallization. These trends add support to the concept that the transition from kakortokite to lujavrite is related to a major physical event, i.e. roof 
subsidence and the development of sub-chambers of small vertical extent. In these subchambers the crystallization and fractionation processes accelerated and cumulus effects were gradually suppressed. The final lujavrites (which include the naujakasite lujavrites) are considered to be close to liquid compositions.

The analytical coverage of $\mathrm{Li}$ and $\mathrm{F}$ in the Ilímaussaq lujavrites and their minerals has been extended and the method and the results are discussed in a paper by J. C. Bailey et al. Both $\mathrm{Li}$ and $\mathrm{F}$ show generally increasing concentrations from the older to the younger lujavrite varieties, but the data also show increasing scatter, and this is an innate feature of these residual rocks. Arfvedsonite is the main Li-bearing mineral in the lujavrites. No single mechanism can explain in detail the $\mathrm{Li}-\mathrm{F}$ variations found.

Gamma-ray spectrometric analyses for Th and $U$ on a large number of all rock types from the Ilímaussaq intrusion are presented in another paper by J. C. Bailey $e t$ al. The rocks show normal $\mathrm{Th} / \mathrm{U}$ ratios (about 3.5 ) in augite syenite and the roof series, but abnormally low ratios, down to 0.5 , in kakortokites and lujavrites (although the later lujavrites, which seem to re-approach magma compositions, return to ratios of about 3.5). The low ratios are related to accumulation of eudialyte with a $\mathrm{Th} / \mathrm{U}$ ratio of about 0.5 . The extensive crystallization of eudialyte should drive residual liquids towards high $\mathrm{Th} / \mathrm{U}$ ratios, but rocks with such high ratios have never been found within the intrusion. This indicates that some material has been lost from the system during crystallization. It is probably some of this lost Th that Nielsen (in Economic Geology section) has found in mineralised veins just outside the intrusion.

\section{Fluid inclusions}

One of the most important properties of an agpaitic magma is its great capability of dissolving volatile components, resulting in very low fugacities of volatile species such as oxygen and sulphur (e.g. Kogarko, 1974). Moreover, abnormal volatile species are present including large amounts of hydrocarbons (Petersilie \& Sørensen, 1970).

Studies of fluid inclusions have been particularly informative concerning the composition and state of the gaseous phase of the agpaitic magmas. Konnerup-Madsen et al. (1979) showed that a hydrocarbon-rich fluid phase existed as immiscible droplets in a highly saline aqueous fluid phase. In their paper here these authors have used their previous analyses of gases in fluid inclusions together with published thermodynamic data to calculate $\log f \mathrm{o}_{2}$ as a function of temperature for the gas phase of the agpaitic rocks of Ilímaussaq. Under the given assumptions, the resulting curve lies well below the synthetic FMQ buffer curve and is yet another expression of the reduced state of the system. The composition of the gas phase of Ilimaussaq is similar to that of the agpaitic Lovozero intrusion: rich in hydrocarbons and $\mathrm{H}_{2}$ and deficient in $\mathrm{H}_{2} \mathrm{O}, \mathrm{CO}_{2}$ and $\mathrm{CO}$, i.e. opposite to that of most other magma types.

\section{Economic geology}

The mineralogical wealth of the llímaussaq intrusion is not only expressed in the number and variety of minerals, but also in its potential economic interest. So far, only occurrences of minerals of uranium and to a lesser extent zirconium, beryllium and niobium have been explored (see reviews by Sørensen et al., 1974; Nielsen, 1976). The history of exploration of uranium has been presented as a case study by Nielsen (1980). 
The present introduction, and the economic geology papers presented in this report, only consider uranium.

A striking feature of uranium geochemistry at Ilímaussaq is the fact that $U$ increases towards the final rock types more rapidly than all other elements. $U$ appears to be the most incompatible element of the intrusion (see Geochemistry section).

The rocks of the intrusion differ from those of most other intrusions in (a) their high contents of $U$ and $T h$ and (b) the great volume of rocks with $T h / U$ ratios less than one. Th and $U$ show a wide range of contents between and within the different rock types, but overall there is a steady increase of median contents from $7 \mathrm{ppm}$ Th and $2 \mathrm{ppm} U$ in the augite syenite to more than $300 \mathrm{ppm}$ Th and $100 \mathrm{ppm} U$ in the final lujavrites.

In most of the Ilímaussaq rocks, Th and $U$ are concentrated in eudialyte, but in the final lujavrites they are largely held by steenstrupine. The stabilization of steenstrupine instead of eudialyte reflects the changing composition of the magma (decreasing $\mathrm{Zr}$, increasing $\mathrm{P}$, $\mathrm{REE}, \mathrm{U}$ ) and perhaps the increasing partial pressure of water and decreasing temperature of consolidation.

During crystallization of the roof series there was a decrease in the $U$ content of the eudialyte from the earlier pulaskite to the later naujaite. This is interpreted by Bohse et al. (1974) and Steenfelt \& Bohse (1975) as a result of diffusion of uranium out of the top cumulates and into the adjacent magma, possibly because of the formation of stable complex ions in the magma. Uranium, together with other trace elements and volatile components, was then squeezed out of the intercumulus melt into the residual magma and this may explain the strong build-up of $U$ and a number of other elements in the magmas forming the latest lujavrites.

Gaseous transfer of elements may have assisted in the formation of the U-rich lujavrites and the contact mineralization in the gabbros and lavas roofing the intrusion as observed at Kvanefjeld. The escaping fluids may have had high $\mathrm{Th} / \mathrm{U}$ ratios as the contact-mineralised roof rocks may have $\mathrm{Th} / \mathrm{U}$ higher than 5 (Sørensen et al., 1969, 1974) and there are Th-rich hydrothermal mineralization occurrences in the country rocks (Hansen 1968; Nielsen, this report).

M. Makovicky reports preliminary results on the distribution of uranium in cores from 70 drill holes in the Kvanefjeld area. The samples represent arfvedsonite lujavrite, naujakasite lujavrite, $\mathrm{M}$-C lujavrite, aegirine lujavrite and contact mineralised lavas.

The role of steenstrupine as a carrier of uranium was especially studied. The steenstrupine crystals are found in all stages of alteration. The host rocks may be strongly hydrated with analcime and natrolite replacing the primary felsic minerals, but no correlation could be observed between the rock hydration and the alteration of the steenstrupine.

Steenstrupine and its alteration products are the only important uranium-bearing phases. The altered varieties of steenstrupine are the most strongly radioactive, and this confirms earlier studies of the mineralization using autoradiography (Buchwald \& Sørensen, 1961).

J. Konnerup-Madsen et al. present preliminary results of a laboratory investigation of the decomposition of steenstrupine. The aim of the work was to delineate the physical-chemical conditions during the later stages of consolidation of the radioactive rocks. Decomposition of steenstrupine was studied in $\mathrm{Na}_{2} \mathrm{CO}_{3}$ solutions at $200-600^{\circ} \mathrm{C}$ and water vapour pressures up to 1000 bars.

Steenstrupine remains after completion of all runs and only a thin outer zone is decomposed. At temperatures above $300^{\circ} \mathrm{C}$ monazite is formed as a decomposition product. An 
unidentified phase is formed in all runs with $\mathrm{Na}_{2} \mathrm{CO}_{3}$ at about $300^{\circ} \mathrm{C}$ (see Table 2 of Konnerup-Madsen et al., this report.

The experiments reveal decreasing concentrations of uranium in the solutions after each run with increasing temperature. This is due to the formation of the refractory phases mentioned above.

The steenstrupine becomes richer in $\mathrm{Na}$ and poorer in $\mathrm{Si}$ with increasing temperature of the runs.

In the paper by B. L. Nielsen radioactive albitites from the contact zone of the intrusion are described at two localities in southern Ilímaussaq. Thorium is strongly predominant in these localities, in contrast to a similar occurrence at the northern contact where uranium predominates (Rose-Hansen et al., 1977).

The albitites occur in strongly faulted, brecciated and altered blocks of country rocks in the exocontact zone. Fluorite is of widespread occurrence. The albitites show vein-like features. The radioactivity is due to thorite, uranothorite and a thucolite-like mineral.

The albitites of the southern localities may result from "powder emplacement" during explosive eruptive events. The tuffaceous breccias recrystallised to form the albitites. This type of mineralization is an important exploration target in future work in the region.

\section{References}

Bailey, J. C., Gwozdz, R., Rose-Hansen, J. \& Sørensen, H. 1978: Preliminary geochemical work on the Ilímaussaq alkaline intrusion, South Greenland. Rapp. Grønlands geol. Unders. 90, 75-79.

Blaxland, A. B., Breemen, O. van \& Steenfelt, A. 1976: Age and origin of agpaitic magmatism at Ilímaussaq, south Greenland: Rb-Sr study. Lithos 9, 31-38.

Bohse, H., Brooks, C. K. \& Kunzendorf, H. 1971: Field observations on the kakortokites of the Ilímaussaq intrusion, South Greenland, including mapping and analyses by portable X-ray fluorescence equipment for zirconium and niobium. Rapp. Grønlands geol. Unders. 38, 1-43.

Bohse, H., Rose-Hansen, J., Sørensen, H., Steenfelt, A., Løvborg, L. \& Kunzendorf, H. 1974: On the behaviour of uranium during crystallization of magmas - with special emphasis on alkaline magmas. In: Formation of Uranium Ore Deposits, 49-60. Vienna: Int. Atomic Energy Agency.

Bondam, J. \& Sørensen, H. 1959: Uraniferous nepheline syenites and related rocks in the Ilímaussaq area, Julianehaab district, southwest Greenland. Proc. 2nd int. conf. U.N. Peace. Atom. Energy 2, 555-559.

Buchwald, V. \& Sørensen, H. 1961: An autoradiographic examination of rocks and minerals from the Ilímaussaq batholith, South West Greenland. Bull. Grønlands geol. Unders. 28 (also Meddr Grønland 162, 11) $36 \mathrm{pp}$.

Emeleus, C. H. \& Upton, B. G. J. 1976: The Gardar period in southern Greenland. In Escher, A. \& Watt, W. S. (edit.) Geology of Greenland, 488-505. Copenhagen: Geol. Surv. Greenland.

Engell, J. 1972: A closed system crystal-fractionation model for the agpaitic Ilímaussaq intrusion, South Greenland with special reference to the lujavrites. Bull. geol. Soc. Denmark 22, 334-362.

Engell, J., Hansen, J., Jensen, M., Kunzendorf, H. \& Løvborg, L. 1971: Beryllium mineralization in the Ilimaussaq intrusion, South Greenland, with description of a field beryllometer and chemical methods. Rapp. Gronlands geol. Unders. 33, 40 pp.

Ferguson, J. 1964: Geology of the Ilímaussaq alkaline intrusion, South Greenland. Part I. Description of map and structure. Bull. Grønlands geol. Unders. 39 (also Meddr Grønland 172,4) 81 pp.

Ferguson, J. 1970a: The significance of the kakortokite in the evolution of the Ilimaussaq intrusion, South Greenland. Bull. Grønlands geol. Unders. 89 (also Meddr Grønland 186,5) 193 pp. 
Ferguson, J. 1970b: The differentiation of agpaitic magmas: the Ilímaussaq intrusion, South Greenland. Can. Miner. 10, 335-349.

Gerasimovsky, V. I. 1969: Geochemistry of the Ilimaussaq alkaline massif (South-West Greenland) (in Russian). Moscow: Nauka, 174 pp.

Gerasimovsky, V. I. \& Balashov, Yu. A. 1968: Geochemistry of rare-earth elements in the Ilimaussaq alkaline massif of SW Greenland (in Russian). Geokhimiya 5, 523-538. (Geochem. Int. 5, 453-467).

Hamilton, E. I. 1964: The geochemistry of the northern part of the Ilímaussaq intrusion, S. W. Greenland. Bull. Grønlands geol. Unders. 42 (also Meddr Grønland 162,10) 104 pp.

Hansen, J. 1968: Niobium mineralization in the Ilímaussaq alkaline complex, South-West Greenland. Rep. 23rd int. geol. Congr. Praha 7, 263-273.

Karup-Møller, S. 1978: The ore minerals of the Ilímaussaq intrusion: their mode of occurrence and their conditions of formation. Bull. Grønlands geol. Unders. 127, $51 \mathrm{pp}$.

Kogarko, L. N. 1974: Role of volatiles. In Sørensen, H. (edit.) The alkaline rocks, 474-487. London: Wiley-Interscience.

Konnerup-Madsen, J., Larsen, E. \& Rose-Hansen, J. 1979: Hydrocarbon-rich fluid inclusions in minerals from the alkaline Ilímaussaq intrusion, South Greenland. Bull. Minéral. 102, 642-653.

Larsen, L. M. 1976: Clinopyroxenes and coexisting mafic minerals from the alkaline Ilímaussaq intrusion, South Greenland. J. Petrol. 17, 258-290.

Larsen, L. M. 1977: Aenigmatites from the Ilímaussaq intrusion, south Greenland: Chemistry and petrological implications. Lithos 10, 257-270.

Nielsen, B. L. 1976: Economic minerals. In Escher, A. \& Watt, W. S. (edit.) Geology of Greenland, 461-487. Copenhagen: Geol. Surv. Greenland.

Nielsen, B. L. in press: The exploration history of the Kvanefjeld uranium deposit, the Ilimaussaq intrusion, South Greenland. In Case Histories of Uranium Exploration. Vienna: Int. Atomic Energy Agency.

Nielsen, B. L. \& Steenfelt, A. 1979: Intrusive events at Kvanefjeld in the Ilímaussaq igneous complex. Bull. geol. Soc. Denmark 27, 143-155.

Petersilie, I. A. \& Sørensen, H. 1970: Hydrocarbon gases and bituminous substances in rocks from the Ilímaussaq alkaline intrusion, South Greenland. Lithos 3, 59-76.

Rose-Hansen, J., Karup-Møller, S., Sørensen, E. \& Sørensen, H. 1977: Uranium-rich albitites from the northern contact of the Ilímaussaq alkaline intrusion. Rapp. Grønlands geol. Unders. 85, 68 only.

Semenov, E. I. 1969: Mineralogy of the Ilimaussaq alkaline massif (in Russian). Moscow: Nauka, $165 \mathrm{pp}$.

Sood, M. K. \& Edgar, A. D. 1970: Melting relations of undersaturated alkaline rocks from the Ilímaussaq intrusion and Grønnedal-Ika complex, South Greenland, under water vapour and controlled partial oxygen pressures. Meddr Grønland 181, 12, 1-41.

Sørensen, H. 1958: The Ilímaussaq batholith, a review and discussion. Bull. Grønlands geol. Unders. 19 (also Meddr Grønland 162,3) 48 pp.

Sørensen, H. 1960: On the agpaitic rocks. Rep. 21st int. geol. Congr. Norden 13, 319-327.

Sørensen, H. 1962: On the occurrence of steenstrupine in the Ilímaussaq massif, Southwest Greenland. Bull. Grønlands geol. Unders. 32 (also Meddr Grønland 167,1) 251 pp.

Sørensen, H. 1967: On the history of exploration of the Ilímaussaq alkaline intrusion, South Greenland. Bull. Grønlands geol. Unders. 68 (also Meddr Grønland 181,4) 33 pp.

Sørensen, H. 1969: Rhythmic igneous layering in peralkaline intrusions. Lithos 2, 261-283.

Sørensen, H. 1970: Internal structures and geological setting of the three agpaitic intrusions - Khibina and Lovozero of the Kola Peninsula and Ilímaussaq, South Greenland. Can. Miner. 10, 299-334.

Sørensen, H. 1974: Alkali syenites, feldspathoidal syenites and related lavas. In Sørensen, H. (edit.) The Alkaline Rocks, 22-52. John Wiley \& Sons, London.

Sørensen, H. 1978: The position of the augite syenite and pulaskite in the Ilímaussaq intrusion, South Greenland. Bull. geol. Soc. Denmark 27, spec. issue, 15-23. 
Sørensen, H. \& Larsen, L. M. 1978: Aspects of the crystallization of volatile-rich peralkaline undersaturated magmas - exemplified by the Ilímaussaq intrusion, South Greenland. Jorn. Miner. 7, 135-142.

Sørensen, H., Hansen, J. \& Bondesen, E. 1969: Preliminary account of the geology of the Kvanefjeld area of the Ilímaussaq intrusion, South Greenland. Rapp. Grønlands geol. Unders. 18, $40 \mathrm{pp}$.

Sørensen, H., Rose-Hansen, J., Nielsen, B. L., Løvborg, L., Sørensen, E. \& Lundgaard, T. 1974: The uranium deposit at Kvanefjeld, the Ilímaussaq intrusion, South Greenland. Geology, reserves and beneficiation. Rapp. Gronlands geol. Unders. 60, $54 \mathrm{pp}$.

Steenfelt, A. \& Bohse, H. 1975: Variations in the content of uranium in eudialyte from the differentiated alkaline Ilímaussaq intrusion, South Greenland. Lithos 8, 39-45.

Upton, B. G. J. 1974: The alkaline province of South Greenland. In Sørensen, H. (edit.) The alkaline rocks, 221-238. London: Wiley-Interscience.

Ussing, N. V. 1912: Geology of the country around Julianehaab, Greenland. Meddr Grønland 38, $376 \mathrm{pp}$.

J.C.B., H.S.,

Institut for Petrologi,

University of Copenhagen,

$\emptyset$ ster Voldgade 10 ,

DK-1350 Copenhagen $\mathrm{K}$.
L.M.L.,

Grønlands Geologiske Unders øgelse, $\emptyset$ ster Voldgade 10 DK-1350 Copenhagen $K$. 